\title{
Politics of Resistance in Pakistan through Progressive Poetry: A Neo-Gramscian Study
}

* Sadia Nazir, PhD Scholar (Corresponding Author)

** Dr. Mazhar Hayat, Professor

\begin{abstract}
The article focuses on locating the politics of resistance in Pakistan through cultural and historical experiences which are materialized through progressive stance of poets especially Faiz (1971) and Jalib (2012). The basic theoretical standpoint of present research paper is Neo-Gramscian in nature. Politics of resistance in poetry is discussed with particular reference to authoritarian rule the Progressivists resisted against. Progressivists highlight the formation of a particular hegemonic process and resistance to it through Progressive poetry. The purpose is to bring to light certain debates by looking into the politics of resistance as counter-hegemony. Politics of resistance becomes a victim of intellectual and political hegemony created through state institutions. The methodology is new-historicist in nature which reinforces that culture and history are material realities. New Historicism evaluates literature through the social and cultural events and also the ways how these socio-cultural events help to build a larger event in creating possibilities for the making of hegemony. It aims at understanding intellectual history through literature and literature through the cultural context surrounding the historical event. The function of new-historicist is to bring home the facts which question the dominant historical functioning of text and bring to light the hidden and untold facts and stories. The basic point of departure of Neo-Gramscian study is to define the premises through which this political and intellectual stance of national politics is largely the part of Bourgeois political and intellectual framework through Progressive counter-hegemonic resistance.
\end{abstract}

Keywords: Hegemony, Politics of Resistance, Progressive Poetry, Counter-Hegemony, NewHistoricism

\section{Introduction}

Resistance has different forms and shapes in different periods. It is inter-discursive and multi-faceted in terms of variety of academia and politics. It was not only resistance against colonialism, rather national narrative which is detached from its representation through common masses and holds the agenda of a dominant class alone. It is a political left which tries to dismantle the narrative of not only right-wing nationalism rather middle class which creates a buffer-zone between masses and Elite by snubbing the resistive potential of proletariat. This middle class could have worked on opening ways for these resistance voices.

Resistance cannot be delimited to single subject and objective only. It develops and transforms itself while shifting from one political period to another. Different moments of changes and development in resistance take place according to changed scenario of political, historical and cultural experiences. Resistance against colonization emerged after World War II. At this juncture in world history, there was a hype of growing consciousness regarding nationalism. This revolution was a major break-through in history as the long period of colonization came to an end. The first phase of resistance we witness was against colonial rule. Anderson (1991) talks about emergence of "imagined communities" in his iconic work Imagined Communities: Reflections on the Origin and Spread of Nationalism. Nation according to him is "an imagined political economy"(p.6) As Anderson puts it, a nation "is imagined because the members of even the smallest nation will never know most of their fellow-members, meet them, or even hear of them, yet in the minds of each lives the image of their communion".(p.7)

But this achievement of new phenomena of nationhood was not an end-product. It brought multiple after-shocks of post-colonial phase with it. The colonial resistance was taking the place of a new kind of resistance of working class against the bourgeois class which served the purpose of those colonial masters. Hence, the nation's soon realized that the freedom and liberty was not actually

* Government College University Faisalabad Pakistan Email: sadiachishti12@gmail.com

** Government College University Faisalabad Pakistan 
practiced rather an old master was replaced by a the new master as Fanon (1963) in his book, Wretched of the Earth, says that middle class "is easily convinced that it can advantageously replace the middle class of the mother country." (p.149) Intellectual leaders actually work as representative of elite and middle class. They don't become the voice of working class, rather seriously damage their cause, "the leader will reveal his inner purpose: to become the general president of that company of profiteers impatient for their returns which constitutes the national bourgeoisie. (p.166) Fanon was one of the earliest theorists to warn about the pitfalls of national consciousness. Fanon describes that national culture has seeds of resistance built in. It is not a populist discourse or prescribed formula. It is developed and transformed through lived experiences, ground realities and cultural facts which people practically do. It is the reality of common masses. It is not what state actors tell them to do. National literature should relate to national consciousness and that national consciousness is not the consciousness of pre-dominant middle class rather it should represent the working class and its ideology as well. Elite of each nation works as a by-product of capitalist bourgeois and it will never let resistive potential of proletariat grow. According to Eagleton (2004), "Third Worldism" gave way to Post-colonialism at first hand, now it poses resistance against "foreign set of exploiters."(p.11)According to Eagleton's After Theory, third world is not a minority. Low paid are also in the first world. And they are neither central nor marginal. The conflict of nations is the conflict of upper-classes against which the resistive potential should be created, "The rich are global and the poor are local, though just as poverty is a global fact."'(p.22)

Hence, we witness this political resistance taking a new shape which is more global in nature. Though this resistance does not emerge as a global collective phenomena but the working class of each nation poses a disparity within nation through class conflict. Globalization with its neo-liberal imperative at one hand does pose an emerging conflict in the form of global resistance from the working classes. Hence, Amoore (2005) in The Global Resistance Reader talks about concept of "global civil society" (p.3) regarding politics of resistance. Hence, there is a concept of "a supranational sphere of social and political participation" and "civil collective agency" (p.4) Resistance as a globalized phenomenon is not only economic and political rather cultural and literary also. For example, South-African anti-Apartheid movement is a kind of localized resistance against globalization and capitalism. When we talk about global and resistance then global, local and transnational all kinds of boundaries are merged. They are neither domestic nor international.

\section{Statement of the Problem}

The study focuses on locating the politics of resistance in Pakistan through cultural and historical experiences which are materialized through literary texts via Progressive poetry.

\section{Objectives of Research}

This research aims at providing the neo-Gramscian perspective of looking at politics of resistance in Pre and Post-Zia regime through Pakistani writings. The military and its role in state-structuring, tackling the global hegemonic influences and dealing with emerging regional and provincial marginal voices of resistance is a primary concern of my research.

The purpose is to highlight multiple debates emerging in poetic works discussing national and ethno-national resistance politics. It links individual social resistance movements to nationalism, globalization and neo-liberal re-structuring of national states. It describes the relation of resistance with globalization. A central question is to whom we refer while talking about politics of resistance. Many phrases are coined to elucidate the term 'resistance'. It also talks about the relevance of international relations with regional and state-centred approaches.

\section{Justification of the Study}

For few, it might look like a subject of politics or journalism but this is not the case. There is a strong link between politics, society, journalism and literature. Literature cannot be developed in a vacuum and it cannot be highly individualistic either overlooking the intricacies and complexities of social and political life. Nawazish (2012) in his article 'Adab Zindagi ar Sayasat' (Literature Life and Politics) writes:

Literature of each era represents the spirit of its age. Spirit of age develops from contemporary life. And if you exclude the element of politics from contemporary life, then it kills spirit of the age. Politics is an important aspect of any era and it is related to whole society. (p.30) (Trans mine) 
A writer cannot dissociate himself from politics. Jalibi (2012) in his article Writer and Politics (Adeeb ar Siyasat) writes:

There are two kinds of attitude concerning writer and politics. One is persistent on the fact that writers too just like students should not take part in politics and they should mind their own business. By minding their own business they mean that writer should continue producing literature and that is all. Such people think that literature is not related to incidents and situation surrounding them. They think that literature springs up from vacuum in the human soul... Writer cannot produce literature if he alienates himself from elements and a circumstance of society ...Literature is related to society and society is related to human beings. (p.445) (Trans mine)

\section{Literature Review}

There are two main trajectories of research. First of all, I will talk about dimensions of global hegemony and how this neo-Gramscian perspective is connected to Pakistani global and internal politics which affects mainstream Progressive politics and creates hindrances in Pakistani experience of democracy, which is also evident in Progressive poetry. Second part deals with counter-hegemony through the voice of resistance in Habib Jalib, Faiz Ahmad Faiz and Fahmida Riaz's poetry aimed at questioning the hegemonic influences of status quo.

Jalal (2013) in The Pity of Partition throws light upon Manto's work. The primary concern is to focus upon the lived historical experience of partition by "unearthing the historical evidence on what led to the colossal human tragedy captured so sensitively in Manto Abajan's Partition stories" as she says, "I considered myself a practitioner of historical narrative" by considering "writing the lectures as the micro-history of the individual and a family with the macro history of communities and states during India's partition" which according to her is "a new historical methodology that imaginatively connects fictional and historical narratives in an attempt to embellish the historian's craft." (P. xi-xii)

\section{Bans, Arrests and Tortures}

Khwaja (2016) in his book People's Movements in Pakistan writes about literary and political writings because they are iconic symbols of resistance. Sattar Tahir wrote Murda Bhutto Zinda Bhutto - The Dead Bhutto, The Living Bhutto. He was later threatened by military. 'Sooraj Bakaf Shab Gazeeda' by Sattar Tahir is about last hours of Bhutto's life in death cell. Copies confiscated book banned. Sattar arrested and tortured and later blacklisted from TV and Radio in Zia's period. Mazdoor Kissan Party's Jamhoori Pakistan magazine was banned. Sindhi Short story writer, painter sculptor Badar Abro was arrested. Dr Salahuddin Hyder doing PhD on Faiz in 1981 arrested tortured and kept in solitary confinement for 75 days. News papers and literary magazines (archives of that time period) like Savera, Naqush, Sang-e-Meel and Adab-i-Latif had to face censorship policies. The outspoken and radical progressive writers like Syed Sibt-e-Hasan, Hajra Masroor, Khadija Mastoor, Ahmad Nadeem Qasmi, Abdullah Malik, Arif Abdul Mateen, Zaheer Kashmiri, Mumtaz Hussain were known as 'Savera Group' (p.453) In 1948, three progressive magazines were banned "under the Public Safety Act for six months. Naqush was proscribed for publishing Manto's Short Story 'Khol Do' (p.454) The first serious criticism on Progressive writers came from Muhammad Hasan Askari who wrote an article titled 'Adeeb ar Riyasat Sy Wafadari Ka Masla: Taraqqi Pasando Pe Kari Tanqeed' (Writers and the Issue of Loyalty with the State: A strong criticism on Progressives) He considers the support of Progressives for East Pakistan for their linguistic economic and ethnic rights as a conspiracy against Pakistan. M.D. Taseer who was earlier a member of PWA broke away with them rather went against them followed by Samad Shaheen, Mumtaz Shireen, and Akhtar Hussain Raipuri. The achievement of nationalism as a finished object was contrary to the idea of challenging the loopholes of emerging official centralized nationalism. So we have right-wing intellectuals at once side and Leftist intellectuals on the other. Right-wing Shorish Kashmiri was against PWA and talked about separating Communism from literature. Ahmad Nadeem Qasmi was left wing intellectual.

On one side are the writers and artists who raise their voice against the oppression and tyranny elite... who support those who are struggling for true freedom peace democracy and socialism, who carry forward the democratic traditions of old literature... On the other side are those writers who serve to translate the designs of ruling class; hide its oppression and tyranny, oppose democratic thoughts and democratic movements." (p.455)

Abdullah Hussain was also a left-wing writer. He criticized the right-wing writers as the "paid propagandists of capitalists and feudal lords." (p.456) Leftist worker Ahmad Bashir along with Tufail 
Ahmad Khan was the editor of weekly Qandil of Nawa-e-Waqt group. Fiction writer and Columnist Ibrahim Jalees wrote a satire of Public Safety Act under the title of 'Public Safety Razor'. He was terminated from Job. Govt. declared APPWA a political organization and spoke against its Communist tendencies. Social and political plays like "Gardish" and "Subha Hone Tak" were banned and alleged as Communists. Maulvi Abdul Haq, father of Urdu pleaded in $2^{\text {nd }}$ APPWA Conference that this ban should be removed because the organization is purely literary and not political. When "Thanda Gosht" was published by magazine Javaid, police raided and confiscated the unsold copies.

\section{Right Wing Association VS Progressive Writers}

Quratul Ain Haider received award from Ayub Khan. Qudratullah Shahab was advisor to Ayub. Altaf Gauhar was also advisor to Ayub. Writers Guild was a right wing association supported by military regime. And it presented the ideological perspective of nation-state. History as a subject was excluded from the courses and replaced by Pakistan Studies. The most vocal literary voice Habib Jalib became famous with his poem "Dastoor" (Constitution), a poem written in protest against the 1962 constitution imposed by Ayub Khan. Jalib recited this poem in front of ministers of General Ayub khan's cabinet. Audience broke into slogans. Another poem Musheer he wrote for fellow poet Hafiz Jallandhari who was advisor to Ayub Khan. Fatima Jinnah was fighting elections against Ayub. Progressive Writers were associated with Rawalpindi Conspiracy case. "The Weekly Jamhuriyat, Peshawar faced army twisting by state because on $18^{\text {th }}$ April 1960, it published a poem with a title of "Rehman Baba" and Pashto" as the establishment considered promoting the languages other than Urdu an anti-state act" (p.456) To protest against the government-formed Commission's decision of "not recognizing the Sindhi language, the Sindhi Adabi Sangat commemorated the Sindhi Language Day on $9^{\text {th }}$ November 1963 to condemn the decision."(p.465) Literary Afkar was banned because it was going to publish Faiz number. 1965 war was a testimony to loyalty of poets and intellectuals. Many were receiving awards and poets like Sheikh Ayaz dared to challenge it. "Ayaz was put behind the bars for writing an anti-war poem, 'He is Sangram that is Naram Shiyam (Renowned Indian Sindhi Poet) his and mine language and narrative are same. How can I shoot him?" (p.466) Hum Ke Thehry Ajnabi A Biography of Faiz by Dr. Ayub Mirza significantly explains poets' struggle through poetics of resistance. In 1967, Faiz and M.R.Hasan formed Awami Adabi Anjuman in Karachi. Its manifesto included all languages, writers and ethnicities. The manifesto translated into Sindhi, Punjabi, Balochi, Pashto and Bengali stated that, "We think that the progress of the nationalities is inter-linked with the democratic freedom. We want that in Pakistan, which is the country of different nations, languages and cultures...All nationalities should have right of self-determination, education in their respective languages, which should have the right to be an official language." Khwaja(2016) writes actress Neelo refused to dance in front of Ayub's guest Shah of Iran, Jalib appreciated this refusal in his poem, 'Tu Ke Nawakif-e-Adab-e-Shehenshahi Thi/Raqs Zanjeer Pehen Kr Bhi Kia Jata $H y$ ' (You were unaware of the norms of the court of emperor, dance could be done with fasten chains.)

\section{Progressive Politics and Ethnic Resistance}

Progressive writers were also working at provincial level, like Baloch PWA and Sindhi Balochi Sangat. Sindhi Adabi Sangat formed in 1982. Badar Abro was part of it. Sindhi Adabi Sangat spoke against oppressive policies in Zia period. Tariq Ashraf Sindhi writer tried in 1984. Multiple activists, writers and journalists were banned and arrested, "The Zia Martial law failed to silence the thundering voice of Habib Jalib whose poem 'Sar Sar Ko Saba, Bande Ko Khuda Kia Likhna' became the warcry in anti-Zia meetings. For writing such poetry, he was arrested several times" (p.494). Another poetic resistance voice was of Ahmad Faraz, whose anti-military poem 'Peshawar Qatilo Tum Sipahi Nahi' was considered much controversial. He was arrested after reciting it in public. Even Faiz death in 1984 was not given much coverage. Faiz poem 'Hum Mehnat Kash Jb Jag Walon Sy" was banned. Zia was invited as a speaker in PWA Golden Jubilee in 1986. Jalib resisted against it, "the only recognized writer who opposed such people leading a progressive event." (p.496) Sibt-e-Hasan resisted through his writing in Zia period too. Professor in University of Balochistan Saba Dashtyari and Vice President of Baloch progressivist organization 'lozchezagh' was gunned down. He was author of 24 books and spoke against military oppression in Musharaf era. Culture and Identity is an important work in this context. Faiz talks about the dichotomy of regional and national cultures and literatures. Both are unifying forces but are in fact creating multiple tensions in wake of rising 
regional and socio-political differences from the pre-dominantly centralized and elite brand of nationalism. Faiz (2005) says about national culture, "it is an aggregate of regional cultures, plus unifying bonds of faith and history."(p.91)

\section{Progressivists against Mullah-Military Oppression}

Jalal (2011) in her article The past as Present talks about the contradiction in people's voice and state narrative. "Despite a well orchestrated official nationalism, Pakistan ever since its creation has been searching for moorings somewhere in the twilight zone between myth and history." (p.9) "History has been reduced to jumble of clichés by official hacks expounding improbable versions of Pakistan's much touted Islamic ideology." (p.10), "By devaluing history for political and ideological reasons, Pakistan has found it difficult to project a national identity that can strike a sympathetic chord with its heterogeneous people." (p.11), "The uneasy symbiosis between a military authoritarian state and democratic political processes is often traced to the artificial nature of Pakistan and the lack of neat between social identities at the base and the arbitrary frontiers drawn by the departing colonial masters." (p.12) Pakistan in return of SEATO and CENTO provided US with "military and economic assistance." (p.13) hence there are stakes of Billion dollar enterprises from US in return of Jihad. "Islamisation policies with American-backed support for the Afghan resistance movement" (p.15)

Manto predicted Mullah military alliance in Letters, "American influence marginalized the Left and weakened incipient democracy without substantially improving the lot of toiling masses. Islam was regularly invoked but religion's role in state affairs was kept in check." (p.14) Lodhi (2011) in her article Beyond the Crisis State talks about "asymmetry between political and nonpolitical."'(p.52) regarding the legitimacy issues in politics. Pakistan's economic growth is a borrowed growth, "Economic management that relied on some one's money permitted the country's rulers to avoid much needed structural reforms that could have placed the economy on a viable self-reliant path. Instead, quick fixes which momentarily created the illusion of good economic management, led to an exorbitant rise in debt as more was borrowed to service old debt." (p.59) Hamid (2011) in his article Why Pakistan Will Survive talks about the pervasive negativity about socio-political scenario in Pakistan. The main issue is the imposition of state religion on people. State does not need to do it. Zia had his own particular version of Islam and it cannot be implemented on all. Cultural diversity should be appreciated and co-existence of multiple religious beliefs in necessary to bring harmony. In 1981, Jalib joined MRD movement against Zia. It was the movement of restoration of democracy. He was well aware of the purpose of democracy in a country. This is quite evident in his poem "democracy".

Nawaz (2011) in his article Army and Politics the patronage tradition of dictatorship and democracy too. "The army meanwhile learned over time to establish patron-client relationships with the bureaucracy and with Islamist parties, whom it used in its efforts to fight internal populist leaders in both East and West Pakistan." (p.82) Shafqat (2011) in his article Praetorians and the People talks about authoritarian tendencies of Elite class. Democracy and economic developments are related. With the process of democratization, economic development increases, while the democracy depends on education, the higher the education the higher the level of democracy. Democracy welcomes cultural pluralism, "Democracy means equality of social classes, minorities and genders."(p.96) Military is also a sort of elite. Till 1980, bureaucracy too was backbone of governmental authority. Political religious and bureaucracy elite all develop a nexus to support the authoritarian rule. Haider (2011) in his article Ideologically Adrift discusses "Islamic ideology as a part of a top-down nationalist project." (p.117) Islam promised to bring social justice but state use it as a tool to deny justice. Consent of the masses is yet to prevail. Sheer ideology is not enough.

\section{Feminist Progressivism}

Khurshid (2008) in her book Memories of Fatima Jinnah shares her memories of Fatima Jinnah and her views on socio-political scenario of Pakistan. Miss Jinnah's example is an example of woman resistance against the military dictatorship. She challenged Ayub in 1964 presidential election. She says about country's condition, "This country came into being because of the sacrifices of a handful of people. However, it has benefited those who had nothing to do with its creation and who made no sacrifice for it." (p.19) Fehmida Riaz' poem Chadar ar Chaar Diwari was a resistance to Zia's oppression on women and draconian laws introduced by him. Feminists like her used poetry as dissent to military oppression, "The poem derives its title from the name of the campaign started by Zia's Islamic ideology,' (p.190) 'Huzoor Me Es Siyah Chadar Ka Kia Karun' is another scathing criticism by Fehmida Riaz. Kirmani, Farrukhi \& Ali (2015) in their work Gender, Politics and Performance in 
South Asia talks about Feminist activism through theatre and arts. Tehrik-e-Niswan came into being in 1979. With political activism, theatre brought cultural activism. General Zia termed performing arts as "un-Islamic". He banned PIA Arts academy, which was a national dance company, "The arts as well as the women of Pakistan were the two major victims of Zia's policies." Women always suffered more and especially in the hands of Zia's policies and "his version of Islamic laws in 1977.

\section{Key Research Questions}

Q1. How does the politics of resistance respond to the state ideology by subverting the hegemonic framework through progressive poetry of Faiz and Jalib?

Q2. How does Political poetry of Progressivists like Faiz and Jalib resist the global geo-political influences weakening the indigenous narrative?

\section{Theoretical Framework}

My theoretical framework will base upon not only Gramscian postulations about hegemony, counterhegemony and the way state and ruling capitalist class use political and intellectual disciplines to maintain power in capitalist societies, but also neo-Gramscian influences regarding hegemony and resistance. The neo-Gramscian study reveals how global hegemonic influences affect not only the national politics rather internal and regional politics as well.

According to Eagleton (2004), such a national narrative is often miscarried and misled by the over-emphasis upon norm and culture, 'which tends to pose harmonious totality.'(p.25) We have two angles to look at this misleading notion. One is homogenizing culture and the other is the voice of the margin. Cultures are naturalized and they are never free-floating. Hence there is a dire need to denaturalize them by time and again challenging the status quo. According to Eagleton, we need a cultural theory of the working class. This is how discourse and relation of signifier and signified works. The Cultural left is anti-capitalist. Third world thinkers like Fanon, Castro, and Cabral talk about this political left. When he refers to the proletariat class, Gramsci (1971) explains the need for the voice of the working class which he terms as 'organic intellectual' while Said calls him 'public intellectual'. Because national narrative is not chalked down as an instruction manual rather it emerges from lived experiences of the masses, as there is a need for the "socialist consciousness to be brought to the working class from outside, the agency he foresees for carrying this out is not the traditional intelligentsia but the revolutionary party itself"(p.4)

Resistance movement always shape and is also constitutive of political and cultural processes. It always works against the oppressive state systems. Gramsci (1971) in Prison Notebooks talks about resistance as counter-hegemony to target state apparatuses. How do state and civil society should work in collaboration to create the equilibrium between disparate voices? He talks about "Organic intellectual". How does he perform the dual function? The working class should have its intellectual who should serve two-fold purposes:

1- $\quad$ Organization of working-class and addressing and articulating their problems

2- $\quad$ Connecting the working class with the ideas of more advanced bourgeois intellectuals.

According to Gramsci, by developing a political and intellectual hegemony, the dominant discourse of power structure can be challenged "the working class like the Bourgeoisie before it is capable of developing from within its ranks its organic intellectuals and providing a link between class and certain sections of the traditional intelligentsia." The organic intellectuals must have "directive" political role (p.4)

Neo-Gramcianism cannot be termed as a specific school of thought. It has a global perspective that loosely connects postulates of Critical Theory with International Relations. Almost all Neo-Gramscians talk about the relation of international relations and hegemonic influences. NeoGramscianism is a sub-part of Critical theory, and it largely addresses the question, "how does global politics shape the state formation?" Gramsci's concept of "good sense" is a critical theorization to subvert hegemony. Hence, hegemony is not restricted to the social and political boundaries of a nation; rather it has its strong links with international relations. In the global world, hegemony too should emerge as a global phenomenon. Gill (2003) says, "Elite is forging the ideology of neoliberalism". Overbeek (1993) calls it "transnational historical materialism" which "identifies state formation and inter-state politics as moments of transnational dynamics of capital accumulation and class formation."(p.9) 


\section{Methodology}

"The historicity of the text and the textuality of history" is the primary concern of new-historicism. The phrase was coined by Stephen Greenblatt around 1980. The concept of "Co-text" is related to "trans-genre" and "inter-discursivity". History and culture are material. Fiction and history crossfertilize each other and stays at a crossroads. Co-literary texts should be referred to have multiple perspectives of history and material reality. "Co-text" lies before and after the text. "Co-text" reenforces the fact that not only a uni-directional way of discourse is enough rather inter-discursive texts should be analyzed to unfold the events in their true spirits so that we may have multiple voices not only through multiple discourse channels rather multiple textual voices as well. For example, two different discourses are there towards a single line of events. For example, ethnic nationalism and anti-state elements are two angles of looked-at-ness. So I will discuss both kinds of discourses. The concept of new- historicism is influenced by Foucault's concept of discourse and power. The embedding of discourse in an inter-discourse is an ideological interpretation of the discourse. Interdiscursivity is not bound to ideology but in more open concepts for analyzing relations between discursive formations, that is mapping their inter-discursive discourses. It describes the regular communications that produce such discourses. Foucault applies this to political economy and national history. The analysis of discourse determines the connection between language, structure, and agency. Discourse is closely linked to politics, policymaking, power, and state. Although New-historicism is not a specific formula but Greenblatt (2000) in Practicing New Historicism points few specific tools to apply it. It aims at challenging the totalizing view of history so one should start with "specific details and anecdote" then we should connect these "specific instances" with "larger contradictory situations "and "Be careful of the narratives that claim liberty because, at a certain point, they too are caught up in a circle of power."(p.197) In Objectivity is not Neutrality-Explanatory Schemes in History, Haskell (1998) talks about interpretations and multiple versions of history. The history of the dominant class is always different from the oppressed class. We need to justify academic freedom in the era of power and knowledge, as "the historicist end of the spectrum in this debate" is recognizing that historicism harbors within itself radical possibilities that are deeply antagonistic (p.117)

\section{Discussion and Analysis of Politics of Resistance in Pakistan through Progressive Poetry}

This research aims at the political and intellectual ramifications of Neo-Gramscian thought in articulating politics of resistance in progressive poetry. The Voice of resistance is the voice of the masses. Eagleton (2003) in After Theory says that the voice of the masses emerges from the historical and cultural location of their experiences. National narrative is not a prescribed formula imposed upon the masses without their will. Such national myths lead to institutional and political failure. Economic resistance not only constitute rather constitutive of political and intellectual resistance. Both cause and affect each other. Multiple debates will be discussed regarding the politics of resistance in progressive poetry. Politics of resistance is not only political but also politicized by multiple global imperatives which is the concern of neo-Gramscian study.

\section{Communism and Progressive Writers}

Mir and Mir (2006) in Anthems of Resistance: A Celebration of Progressive Urdu Poetry gives a critical insight into Progressive poetry. Progressivist critique of neo-colonial state was done through Progressive Writers Association. Progressive papers Limited was run by Mian Iftikharuddin who was a staunch socialist.

The establishment, in turn, launched an assault on the Left through a multi-pronged strategy: discrediting the socialist vision by using the Cold War propaganda, presenting the Progressives as Fifth columnists and enemies of the Pakistani nation-state, and consolidating the ideological front against them within the literary-cultural sphere. These measures were backed by the coercive power of the state which was increasingly directed against progressive publications and members of the association. Meetings were regularly disrupted, publications proscribed and activists imprisoned. (p.15)

Progressivists were charged with conspiring to overthrow the government. Communist Party of Pakistan was banned as a result of inquiries of Rawalpindi Conspiracy case. Sibt-e-Hasan was running Lail-O-Nehar. Imroz was edited by Ahmad Nadeem Qasmi and Pakistan Times was edited by Faiz and Mazhar Ali Khan. All progressive magazines were closed but it could not destroy the spirit of progressivism to be later witnessed as voices like Jalib and Faraz in the 1960s and '70s, and voices like Fehmida Riaz and Kishwar Naheed in the 1980s. Dastoor by Jalib criticizes Ayub's constitution 
in 1962, "Jalib's characteristic sarcasm is on ample display in his poem, skewering the rulers of Pakistan and their subservience to the neo-imperialist order." (p.19) His poem 'Firangi Ka Jo Main Darban Hota' speaks a lot about this. Halqa-e-Arbab-e-Zauq (The Association of the Aesthetes) was in opposition to PWA. But Faiz was progressive aesthetic. Jalib was called Awami Shayar 'Poet of the People'. According to them, Ghazal was anti-Progressivist.

The Progressivists fashioned a new poetic tradition, turning the conventional metaphors of shama-parwana (flame-moth), firaaq-visaal (separation-union), and husn-ishq (beauty-love) on their heads in the service of a new aesthetic of social change. Instead of writing ghazals about pinning lovers, they penned popular poems to celebrate progress and modernity. Instead of elegies to Majnoon and Farhad, they composed dirges about martyred revolutionaries like Patrice Lumumba and Martin Luther King. (P.21-22)

\section{Egalitarianism and Progressive Poetry}

Progressivist poetry is the new wine in old bottles, "bulbul-sayyad (nightingale-hunter), sagar-jaammeena (goblet-wine-flask) and gul-bahar-khizan (rose-spring-autumn) remained its dominant themes. It took the iconoclasm of the PWA poets to shatter this mold." (p.34) and this renewed sensitivity was re-charged with progressive meanings. The standards of beauty are transformed. The suffering of a lover is now replaced by the suffering of humanity. Faiz was both progressive and aesthetic. Josh Maliabadi's East India Company Ke Farzandon Sy is anti-imperialist. Zaheer Kashmiri and Sahir Ludhianvi were greatly influenced by the 'Telangana' Peasant Movement. Progressive poetry is related to the issue of nationalism and this nationalism is not the nationalism of leaders. It is the nationalism of the masses. It promotes justice and egalitarianism, not the elitist authoritarian rule which only qualifies official and state nationalism. Faiz's poem Hum Jo Tareek Rahon Mein Maray Gaey is written for Julius and Ethel Rosenberg executed on charge of being Russian spies. Kaifi Azmi's Ibn-e-Maryam is also this kind of poem. He addresses Jesus Christ by referring to Christian wars in the name of good cause. Sahir Ludhianvi's Khoon Phir Khoon Hy also addresses oppression and injustice faced by human beings. It is written on the murder of Congo's PM Patrice Lumumba. Faiz wrote about Lebanon and Palestine. Faiz was exiled to Lebanon during the dictatorship of Zia. His poem 'Ek Tarana Falasteni Mujahidon Ke Naam' and 'Sar-e-Vaadi-e-Sina' had the similar context. And about Beirut he wrote Ishq Apny Mujrimo Ko Pabajolan Le Chala. Mat Ro Bache by Faiz addresses Palestinian child who has become Orphan. His whole book Mere Dil Mere Musafir was dedicated to Palestinian leader Yasser Arafat. Jalib taunted Zia-ul-Haq in a ghazal "Jahan Khatry me hy Islam Os Maidan me Jao". He was trying to Islamize Pakistan not a single word for atrocities on Palestinians. Internationalism of Progressivists in informed by "an understanding of shared mater working-class of oppression and struggle and was inspired by the international working class movements," (p.81)

\section{Progressivists, Faiz and Rawalpindi Conspiracy Case}

Jalal (2017) in her recent book The Struggle for Pakistan: A Muslim Homeland and Global Politics Ambitious wife of Major General Akbar Khan contacted Leftists of Communist party including Faiz who was editor of Pakistan Times owned by Communist Mian Iftikharuddin "Rawalpindi Conspiracy as the foiled coup attempt came to known aimed at establishing a tyrannical military dictatorship with cocasesist backing." (p.80) Faiz composed finest poetry while jailed in conspiracy case. Sheeshon ka Masseha Koi Nhi well explained by Jalal, "Oppressors who lived in glass houses, pretoverlordshipere messiahs. If the fortunes of tyrants were soaring today, their over lordship would soon come to an end. Pillagers and looters could neither hide nor empty the nation of its manifold riches, which belonged to the hungry and distressed people of the land." (p.80) Politics of resistance is quite evident in Faiz (1971)' poem 'Speak':

$$
\begin{aligned}
& \text { Speak, your lips are free. } \\
& \text { Speak; it is your own tongue. } \\
& \text { Speak; it is your own body. } \\
& \text { Speak; your life is still yours. }
\end{aligned}
$$

Toor (2011) in her book The State of Islam: Culture and Cold War Politics in Pakistan discusses the opportunist uses of Islam. Loyalties of minorities are always questioned based on their choice of religion. Ayyub banned the communist party and Governor-General Ghulam Muhammad's scandalous formation of one unit was a vicious plan to reduce the power of Bengalis. In this way power always played with the naïve and those who ask for their genuine rights, equality, and justice. 
NAP had the support of Bengalis because its agenda was socialist. Faiz was arrested in Ayub's period. And Sibt-e-Hasan too was arrested. Hasan Nasir was tortured in 1962. A brutal killing of the voices of dissent it was. Jamaat-e-Islami Fascist Bourgeoisie was using Islam against Communism. Zia under the cover of piety expanded militarization and Islamization. Akhtar (2018) in his book The Politics of Common Sense: State, Society, and Culture in Pakistan discuss many faces of Islam, "The political and cultural repression that took place under the guise of Islamization had far-ranging impacts across the length and breadth of society." (p.102) MQM is a secular right-wing party. Hence religion is not the only tool to kill voices of dissent. It's the more the agenda of the power. (p.104) though MQM had close ties with Zia. Islam is not just an elite's tool. It's a cultural fabric widely accepted. It is accepted by both political and civil society to exercise hegemony. In 1960's/1970's we witness the political activism of the left but later in Zia's period, politics of resistance was badly crushed in the name of Islam. Idiom of Islam remains at the forefront of Pakistani politics, and is invoked by all and sundry as the ultimate fountainhead of statecraft." (p.111)

\section{Purpose of Progressivists and Democratic Process}

Coppola (2017) in his book Urdu Poetry, 1935-1970: The Progressive Episode gives chronological details of progressive poetry. The purpose of the Progressive Writers Association was to "struggle for a people's democracy against the forces of capitalism." (p.231) "The writers must present the desires and hopes of the people, who are not only being exploited by the foreign imperialists but also by the Indian capitalists, landlords and Raj Wallahs. These are the purposes which have guided the new progressive literature" (p.239). The literature which promotes Art for art's sake tends to be imperialist and individualist. There were two kinds of schools of thought regarding poetry. One was Arbab-eZauq and the other was termed as Tarraqi Pasand. Muhammad Hasan Askari was a right-wing intellectual who halted the path of Progressives. His writings criticized Progressivists, "always provided government with legal and ideological support instilling an expression of dissent." (p.299) but he was against banning them. Zaheer Kashmiri's journal Savera was also banned under Public Safety act Ordinance. Ahmad Nadeem Qasmi was secretary of APPWA. Zaheer Kashmiri says Progressivist literature is "about life and struggle to improve social life." (p.303) Writers like NM Rashid Manto and Meeraji do not come under the progressive banner but they write about life. Mah-eNau, Nayadaur, Saqi, and Urdu Adab were Art for Art's sake journals. Rawalpindi Conspiracy case put Progressivists in bad light. And then with Ayub's takeover of progressive papers limited, the backbone of Progressive writers was broken. Rumi(2018)'s Being Pakistani explores literature as a voice of resistance against oppression, "as literature has also been a powerful instrument of political resistance through dictatorships; and more recently poets and writers have confronted extremism that afflicts contemporary Pakistan.'(P. viii)

\section{Jalib-The People's Poet}

Habib Jalib is called the poet of the people. He becomes the voice of the masses against the tyranny of authoritarian rule. He tries to empower people through democratic norms. He develops selfconsciousness and self-awareness among the masses through his poetry. He is a progressive spirit. Jalib is a symbol of counter-hegemony and resistance. He similarly invokes the revolutionary spirit as Gramsci invokes. His poem 'Constitution' becomes the emblem of resistance. He openly challenges the dictatorial rule of General Ayub and General Zia and demands the supremacy of law and restoration of the democratic constitution. This poem is a critique of the undemocratic nature of General Ayub's constitution of 1962 which was presidential. The title of the collection of poetry (which includes this poem) 'Sar e Maqtal' (Near the Slaughterhouse) itself provokes the resistance, protest, and voice of dissent against violent repression. In Ayub's era, Jalib recited this poem in All Pakistan Mushaira in Murree. He was already warned that he would be banned and will be sent to jail but he never cared. The atmosphere was anti-Ayub but nobody was courageous enough to say this on the face of tyranny. This was an iconic example of resistance and political activism. This is what confrontational politics takes, confronting the authority and never caring about the consequences. The crowd became so much charged with his recital that the audience was on roads and converted into a sort of public procession. Hence constitution is a highly charged political poem. His poem became famous and the news was spread like a wildfire. Hence, Dastoor becomes a great resistance poem. Each line explains the political reality and resistance against it in a revolutionary manner. All the lighted lamps are for palaces. All the benefits and all the facilities are for elitist authoritarian rule. There is nothing for the common man. No lamps are lighted for the common masses. Their lives are 
not made easy. They are suffering in a similar manner they suffered in the colonial rule. Compromises are made for the betterment of not the country rather for the elite and that too at the expense of common people. Jalib questions it. This is not dawn. This is not freedom. If we are independent and free then why we can't make an end to people's suffering. Jalib (2012) openly rejects such a system. This rotten system is aggravating the problems of poor masses. Such constitution is adding to the miseries of the people:

That which lights lamps only in palaces

That which caters to the whims of the elite classes

That which flourishes in the shadow of all compromises

Such a system, such a light-starved dawn

I do not agree with you! I do not abide!

Jalib's scathing criticism of military oppression is so apparent in his poem "The Government of Jack Boots":

\author{
If the dacoit had not had \\ The village guard as his ally \\ Our feet would not be in chains \\ Our victory would not defeat implyMourn with turbans around your necks \\ Crawling on your bellies, complyOnce the jackboot government is up \\ It's hard, to make it bid good-bye
}

Jalib (2012)'s poem Mullah is a scathing criticism against the misuse of religion for oppressing progressive voices of resistance:

Too long I have heard you preach and prate, Maulana

But so far there has been no change in my fate, Maulana

Keep to yourself your preachings of gratefulness

My heart, like an arrow, they penetrate, Maulana

Akhtar (2018) in his book The Politics of Common Sense: State, Society, and Culture writes that the Politics of 'the oppressed' leads to revolutionary politics through resistance and counterhegemony. Such resistance erupted in Ayub's dictatorship. On the one hand, Gramsci's ideas have become very much part of the mainstream (western) academy. On the other hand, this mainstreaming equates to Gramsci being invoked excessively as a scholar of the discursive realm separated by academic fashion from the materialist concerns which underlay his efforts." (P. ix) My concern is to focus on politics of resistance as a counter-hegemony, which according to Gramsci can be achieved through "national-popular collective will". (P. x) West Pakistan bureaucracy and landlords were all on one page. We witness the rise of Left in Ayub's period. Labour became organized and student movements were on peak, "The coalescing of progressive intellectuals, students, political activists and a cross-section of the subordinate classes had the makings of a counter-hegemonic historical bloc in its own right." (p.13) He talks about Gramscian building blocks and "the counter-hegemonic power of the sub-ordinate classes" (p.14) The historical Bloc is the continuation of same colonial power, "The sociological roots of militarism in Post-colonial Pakistan can be found in the unique social contract established in colonial Punjab under the British." As the "hegemony exists in the form of a complex dialectic of coercion and consent, in the complementary role of the state as the repository of power and civil society as the terrain of common-sense action."(p.15) Structure of power operates from above while the counter-hegemony operates from below "An analytical engagement with the structure of power 'from below' cannot however take the place of more traditional concerns with the state, propertied classes and geo-politics." (p.32) Pakistan's patronage-based political order was fashioned under the same British way to rule. NAP was the leftist party of Balochistan. Leftists and ethnic nationalists were successful in NWFP and Balochistan. "The Party's Leftist component was nevertheless significant and its dismissal by the central government so soon." (p.120) as "symbiotic relationship between class and ethnicity was a major pillar of the politics of resistance through the 1970s." (p.121)There is no party like NAP to unite the working class under one place... No counterhegemonic politics. "counter-hegemonic ideologies and active political movements of resistance have to contend with the everyday compulsions of ordinary people seeking to survive the system, including those occupying the lowest rung of the sub-ordinate classes." and of "ethnic nationalist politics" though state nationalism never tried "redressing the ethnic-linguistic fissures."(p.129) 1960's and '70s were the heyday of radicalism in Pakistan. The development of politics of the Left throughout decades 
teaches us about hegemonic influences as well. Politics of Left was thriving in Ayub's era. In the period of industrialization and urbanization, people were coming to cities, especially workers, laborers, and peasants. Separation of East Pakistan as a result of such militant oppression which was later handed over to General Yahya but he was unable to bear the consequences. Jalib's poem Baghiya Lahoo Lahoo addresses East Pakistan debacle:

$$
\begin{gathered}
\text { The rays of the sun, they sting } \\
\text { Moonbeams are a killing field, no less } \\
\text { Deep shadows of death hover at every step } \\
\text { Life wears a skull and bone dressAll around the air is on the prowl } \\
\text { With bows and arrows, in full harness } \\
\text { The garden is a bloody mess }
\end{gathered}
$$

While resisting against Zia's rule, he wrote a famous poem Zulmat Ko Zia. Jalib was arrested thrice in Zia's period. He openly conveys this message through his poem, "Why should we call Darkness, light?" He creates a pun over the literal meaning of the word "Zia" which means light. According to Jalib, such dictators are symbols of darkness. Why should we call them light? Light is a symbol of freedom, change, and awareness:

$$
\begin{gathered}
\text { Every evening here is one of desolation, } \\
\text { Every road and alley is struck by calamity, } \\
\text { With hope in our hearts, we searched for a city, } \\
\text { Where is that city now, my devastated heart? } \\
\text { This desert as a rose garden, } \\
\text { This cloud as silver lining I cannot write } \\
\text { This night as dawn, these toxic fumes as a breeze } \\
\text { And a human as god I cannot write. }
\end{gathered}
$$

Conclusion

The working class continues to suffer from long-term oppression by Bourgeoisie's intellectual and political stance. Bourgeois nationalism stands against cultural and historical nationalism which reinvokes itself through political left and power of resistance through Progressivist stance in Pakistan. This research paper aims at the political and intellectual ramifications of Neo-Gramscian thought in articulating politics of resistance through Progressive Pakistani poetry. The Voice of resistance is the voice of the masses. The Voice of the masses emerges from the historical and cultural location of their experiences. National narrative is not a prescribed formula imposed upon the masses without their will. Such national myths lead to institutional and political failure. Multiple debates are discussed regarding the politics of resistance through Progressive Pakistani literature. Politics of resistance is not only political but also politicized by multiple global imperatives which are the concern of neoGramscian study.

\section{Findings}

The study suggests the working mechanism of political activism which strengthens the voice of the masses because the stronghold on people's politics and its progressive outlook can bring transformation in the system. Progressivists recommend transformational politics in the political and social arena. We need to find our battles and struggle to resolve them. The eternal war between the Bourgeois and the working-class and their clashing values not only affected our indigenous politics but how the voices of resistance faced multiple challenges in wake of their free choices of claims to equality and all the other promises hegemonic forces offer to the world. There is a need to break this hegemony through resistance as counter-hegemony which is the concern of Neo-Gramscian politics.

\section{References}

Akhtar, A. S. (2018). The politics of common sense: State, society and culture in Pakistan. UK: Cambridge University press

Amoore, L. (2005). The global resistance reader. London; New York: Routledge

Anderson, B. (1991). Imagined communities: Reflections on the origin and spread of nationalism. London: Verso.

Coppola, C. (2017). Urdu poetry, 1935-1970: The progressive episode. Karachi: Oxford University Press

Eagleton, T. (1996). Literary theory: An introduction. Minneapolis, MN: University of Minnesota Press. 
Faiz, F. A. (2005). Culture and identity. Karachi: Oxford University Press

Faiz, F. A. (2000). Poems by Faiz. (V.G.Kiernan, Trans.). India: Oxford University Press

Fanon, F. (1963). The wretched of the earth. New York: Grove Press.

Gramsci, A. (1971). Selections from the prison notebooks. In: Q. Hoare and G. N. Smith (Ed).London: Lawrence and Wishart.

Gill, S. (2003). .Power and resistance in the new world order. Basingstoke: Palgrave Macmillan.

Gallagher, C \& Greenblatt, S. (2000). Practicing new historicism. Chicago: University of Chicago Press.

Hamid, M. (2011). Why Pakistan will survive? In: M. Lodhi (Ed), Pakistan: Beyond the crisis state. USA: Columbia/Hurst.

Haider, A. (2011). Ideologically adrift. In: M. Lodhi (Ed), Pakistan: Beyond the crisis state. USA: Columbia/Hurst.

Haskell, T.L (1998). Objectivity is not neutrality. Baltimore, Maryland. London: The John Hopkins University Press.

Jalal, A. (2011). The past as present. In: M. Lodhi (Ed), Pakistan: Beyond the crisis state. USA: Columbia/Hurst.

Jalal, A (2014). The struggle for Pakistan.USA: Harvard University Press.

Jalal, A. (2013). The pity of partition. Karachi: Oxford University Press.

Jalib, H. (2012). Kulliyat-e-Habib Jalib. Lahore: Tahir Sons Publishers

Jalibi, J. (2012). Writer and politics (Adeeb ar Siyasat. Lahore: Sang-e-Meel Publications

Kirmani, S. Farrukhi, A \& Ali, K..A (2015). Gender, politics and performance in South Asia. Karachi: Oxford University Press

Khurshid, S. (2008). Memories of Fatima Jinnah. (K. Hasan, Trans.). Lahore: Sang-e-Meel Publishers

Khwaja, A. (2016). People's movements in Pakistan. Karachi: Kitab Publishers

Lodhi, M. (2011). Pakistan: Beyond the crisis state. In: M. Lodhi (Ed), Pakistan: Beyond the crisis state. USA: Columbia/Hurst.

Mir, A. H. \& Mir, R. (2006). Anthems of Resistance: A celebration of progressive Urdu poetry. New Delhi: Roli Books India Ink

Nawazish, K. (2012). Literature, life, and politics (Adab Zindagi ar Sayasat). Faisalabad: Misaal Publishers

Nawaz, A. (2011). Army and politics. In: M. Lodhi (Ed), Pakistan: Beyond the crisis state. USA: Columbia/Hurst.

Overbeek, H. (1993). Restructuring hegemony in the global political economy: The rise of transnational neo-liberalism in the 1980s.London: Routledge.

Rumi, R. (2018). Being Pakistani: Society, culture and the arts. India: Harper Collins.

Shafqat, H. (2011). Praetorians and the People. In: M. Lodhi (Ed), Pakistan: Beyond the crisis state. USA: Columbia/Hurst.

Toor, S. (2011). State of Islam. London: Pluto Press. 